AnNA IRENA SZYMAŃSKA

Uniwersytet Pedagogiczny, Kraków

\title{
Implementacja systemu TQM w podnoszeniu pozycji konkurencyjnej przedsiębiorstwa przemysłowego
}

Współczesny rynek stawia przedsiębiorstwom coraz to nowe, wyższe wymagania, co sprawia, że muszą one być coraz bardziej konkurencyjne. Efektem działania gospodarki rynkowej ukierunkowanej na klienta, jego potrzeby i oczekiwania jest dążenie podmiotów gospodarczych do świadczenia usług na najwyższym poziomie. Możliwość realizacji potrzeb konsumentów poprzez oferowanie produktów i świadczenie usług na poziomie międzynarodowym stanowi sposób wyróżnienia działalności firmy na nasyconym rynku. Dotrzymywanie kroku w dziedzinie jakości, będące ważnym atutem w walce konkurencyjnej coraz częściej staje się wyznacznikiem działalności przedsiębiorstw.

Poszukiwanie sposobów osiągnięcia trwałej i wyróżniającej przewagi konkurencyjnej stanowi poważne wyzwanie dla kadry menedżerskiej. Skonstruowanie takiego systemu zarządzania, który wyeliminuje z cyklu ekonomicznego firmy wszystkie niedociagnięcia i zapewni zorientowanie na efektywność, sprawność i niezawodność, to podejście do problematyki zarządzania podejmowane przez przedsiębiorców pragnących realizować strategię osiagania przewagi konkurencyjnej w oparciu o TQM.

TQM stanowi metodę innowacyjnego podejścia do zarządzania organizacją, promująca budowanie kompleksowej, indywidualnej kultury organizacyjnej przedsiębiorstwa na gruncie wspólnych celów i wartości. Realizacja założeń konkurencyjnego przedsiębiorstwa odbywa się tu w oparciu o specyficzny kod zadań, w którym jakość stanowi kluczowy element spajający wszystkie sfery funkcjonowania organizacji. Zachodzące w przedsiębiorstwie procesy i szeroko pojęty kapitał zakładowy tworzą swoistą mapę funkcjonalną firmy.

\section{EWOLUCJA SYSTEMU ZARZĄDZANIA W ASPEKCIE HISTORYCZNYM}

Doskonałą ilustracją rosnącego znaczenia zagadnień jakości jest historyczna ewolucja podejścia do organizacji i zarządzania przedsiębiorstwem, w ramach której wyróżnić można trzy charakterystyczne okresy.

Historycznie najwcześniej dominowało zarządzanie przez produkcję. Przedsiębiorstwa stosujące ten typ zarządzania koncentrowały swoją uwagę na maksymalizacji produkcji i wydajności przede wszystkim poprzez intensyfikację wysiłku fizycznego i umysłowego 
pracowników, zwiększenie zmianowości, poprawę stopnia wykorzystania zdolności produkcyjnych. Następny okres to zarządzanie przez marketing. Tu uwaga przedsiębiorstwa koncentrowała się na badaniu i rozbudzaniu, a następnie zaspokajaniu potrzeb odbiorców. Zmienność owych potrzeb powodowała zmienność wymagań jakościowych produkowanych wyrobów i świadczonych usług. Szybkość i trafność decyzji, dotyczących jakości wyrobów i usług, określała ich pozycję na rynku i wpływała na sytuację finansową przedsiębiorstwa. Pojawienie się konkurencji jakościowej między dostawcami wywołało zmianę w podejściu do zarządzania. Organizacyjnym symptomem takiej zmiany stały się wyodrębnione w przedsiębiorstwach podsystemy, których przedmiot działania obejmował całość zagadnień jakości produkcji i świadczonych usług.

Trzeci okres rozpoczął się pojawieniem podejścia zwanego zarządzaniem przez jakość. Jego zasadniczą cechą stało się traktowanie jakości jako uniwersalnej formy wdrażania celów społecznych w sferze produkcji i spożycia. W tej sytuacji każda dziedzina działalności przedsiębiorstwa powinna stanowić obiekt sterowania jakością. Nadal w przedsiębiorstwach produkcyjnych obszar produkcji uważany jest za kluczowy, gdyż stanowi miejsce podejmowania decyzji rozstrzygających o poziomie jakości wyrobów i zaspokajaniu za ich pomocą określonych potrzeb. Właśnie określenie tych potrzeb jest zadaniem obszarów marketingowych. Stąd nie produkcja, a właśnie marketing stanowi źródło wszystkich informacji o potrzebach i oczekiwaniach rynku. Wiele przedsiębiorstw pozostaje nadal w drugim okresie rozwoju jakości, nie rozumiejąc bezwzględnej potrzeby przeorientowania na zarządzanie przez jakość.

Wynikiem rosnącej świadomości znaczenia jakości jest powstanie TQM (Total Quality Management), w którym miejsce centralne zajmuje cały proces funkcjonowania i pracy firmy, a jakość produkcyjna jest jedynie jej aspektem.

\section{PoJęCIE ORAZ ELEMENTY SYSTEMU TQM}

Literatura przedmiotu dostarcza dużej różnorodności podejść w sposobie definiowania pojęcia Total Quality Management (TQM), określanego jako kompleksowe zarządzanie przez jakość. Różnice w sposobie definiowania wynikają przede wszystkim z powiązań oraz wzajemnego przenikania się teorii i praktyki. Naturą praktyki gospodarczej jest różnorodność. Różnorodne są przedsiębiorstwa, ich zasoby i rynki, na których działają. Nie może więc być tu mowy o uniwersalnych, zunifikowanych zasadach i narzędziach. Zastosowane metody i środki muszą uwzględniać elementy specyficzne dla danego przedsiębiorstwa, zwłaszcza że TQM ma zastosowanie nie tylko w przedsiębiorstwach przemysłowych, ale również organizacjach usługowych, służbie zdrowia, szkolnictwie itp.

Definicje TQM różnią się również stopniem szczegółowości. Jedne uwzględniają jedynie zasadnicze elementy, w innych natomiast przedstawia się także stosowane techniki i narzędzia. Większość definicji łączy eksponowanie kluczowych elementów TQM, takich jak:

- orientacja na klienta (zewnętrznego i wewnętrznego),

- proces ciągłych zmian i usprawnień,

- „totalne”, świadome wagi jakości, zaangażowanie pracowników na wszystkich szczeblach wraz z zapewnieniem przywództwa i pracy grupowej,

- doskonalenie przez ciągłą edukację realizowaną w ramach programu szkoleń i treningów, 
- zapewnienie ciągłej zdolności do dostosowywania kluczowych procesów, przy ścisłej obserwacji i pomiarze,

- dążenie do kształtowania pożądanych stosunków z dostawcami (Karaszewski 2001, s. 88; Hill 1991, s. 379-382).

Ogólnie rzecz biorąc, TQM to system zarządzania bazujący na sposobie myślenia całego personelu. Jest to całościowe i systematyczne podejście do zarządzania organizacją oparte na ciągłym doskonaleniu jakości wyrobów i usług z punktu widzenia klienta. TQM to filozofia zarządzania, która przez odpowiednią strategię, procesy, kształcenie, motywację, zaangażowanie, narzędzia i środki prowadzi do sukcesu przedsiębiorstwa, który ma swoje odzwierciedlenie w zadowoleniu i pełnej satysfakcji klienta (Skrzypek 2000, s. 101).

Podwaliny systemu TQM stworzone zostały jeszcze na początku lat 40. XX w. Współtwórcami dotychczasowych osiągnięć w zakresie zarządzania przez jakość (TQM) są głównie badacze praktycy i teoretycy ze Stanów Zjednoczonych, Japonii i Europy Zachodniej, zajmujący się problematyką jakości w przedsiębiorstwach produkcyjnych. Od początków XX w. istniejący tam system dynamicznie rozwijającej się gospodarki rynkowej wywierał presję na praktyczny i modelowy postęp w zakresie jakości produktów. Powstawały koncepcje autorskie zarządzania jakością jako zestawy poglądów praktyków, konsultantów i naukowców. Za prekursora w tej dziedzinie uznawany jest W.E. Deming, który rozwinął wprowadzone przez A.V. Feingengauma TQC (Total Quality Control), a ogólne zasady TQM zawarł w tzw. czternastu punktach. Zasadę funkcjonowania systemu TQM bardzo dobrze przedstawia „łańcuch Deminga”. Istotne jest tu, aby zajmować się całością zagadnienia i w odpowiedniej kolejności, od początku do końca. Do grona najwybitniejszych prekursorów koncepcji TQM zalicza się również Josepha Jurana ${ }^{1}$ oraz Philipa Crosby’ego².

Porównując poglądy najważniejszych teoretyków i praktyków zajmujących się koncepcją zarządzania przez jakość (TQM), można odnaleźć pewne podobieństwa (Karaszewski 1999, s. 88):

- pełne zaangażowanie najwyższego kierownictwa jest warunkiem koniecznym,

- praktykowanie zarządzania jakością oszczędzi, a nie zwiększy koszty,

- odpowiedzialność kierownictwa,

- konieczność ciągłego i stałego udoskonalania,

- zaspokojenie potrzeb klienta w centrum zainteresowania,

- partnerstwo na linii kierownictwo-pracownicy,

- konieczność wprowadzania zmian w ramach kultury organizacji.

Podstawowym celem systemu TQM jest zapewnienie zadowolenia klientów organizacji (zewnętrznych i wewnętrznych) poprzez właściwe zarządzanie i doskonalenie realizowanych procesów. W ramach systemu zazwyczaj wyróżnia się trzy podstawowe elementy, stanowiące jego główne filary. Są nimi: zespoły, system oraz narzędzia.

W celu prawidłowego realizowania założeń systemu TQM konieczne jest zaangażowanie nie tylko ze strony kierownictwa, ale również wszystkich pracowników, którym zależeć będzie na doskonaleniu jakości i realizowaniu wymagań klientów. Praca w odpowiednio

${ }^{1}$ Joseph Juran uważał, iż najważniejszym czynnikiem upowszechnienia nowych rozwiązań w zakresie zarządzania jakością jest jasna i zrozumiała prezentacja zasad i koncepcji kierownictwom wyższych szczebli. Opracował on triadę procesu zarządzania: planowanie jakości, kontrola jakości, usprawnienie jakości. jakości”.

2 Philip Crosby sformułował koncepcję ,zero defektów” będącą integralną częścią czterech „,pewników 
zorganizowanych zespołach powinna polegać na dążeniu do stałej poprawy jakości wytwarzanych produktów oraz usprawnianiu realizowanych procesów.

Z uwagi na fakt, iż TQM jest nieustrukturalizowaną filozofią zarządzania jakością, konieczne jest opracowanie systemu, który pozwoli na uporządkowanie prowadzonych w ramach organizacji działań oraz uściśli zakres odpowiedzialności i uprawnień. Natomiast współuczestniczenie wszystkich pracowników w procesie doskonalenia organizacji wymaga wykorzystania odpowiednich narzędzi do nadzorowania procesów oraz wspomagania zespołów (kół jakości) zajmujących się doskonaleniem jakości.

W literaturze przedmiotu wymieniane są różne elementy systemu TQM. I tak na przykład E. Skrzypek (2000, s. 93) wymienia: strategię, kształcenie, narzędzia, sukces, motywację i procesy. Nieco inny zestaw elementów podaje J.S. Oakland (2004, s. 12-20, 35). Proponuje on nowy model zarządzania przez jakość. W modelu tym kluczową rolę odgrywają procesy, które wiążą pozostałe trzy elementy: planowanie, ludzie i rezultaty (4Ps). Owe cztery elementy tworzą podstawę modelu zarządzania przez jakość. Wokół tej podstawy skupiają się „miękkie” elementy: kultura, komunikacja i zaangażowanie (3Cs). Zintegrowanie wszystkich siedmiu wymienionych wyżej elementów (4Ps+3Cs) może uczynić z organizacji podmiot odnoszący sukcesy w przyszłości (ryc 1.).

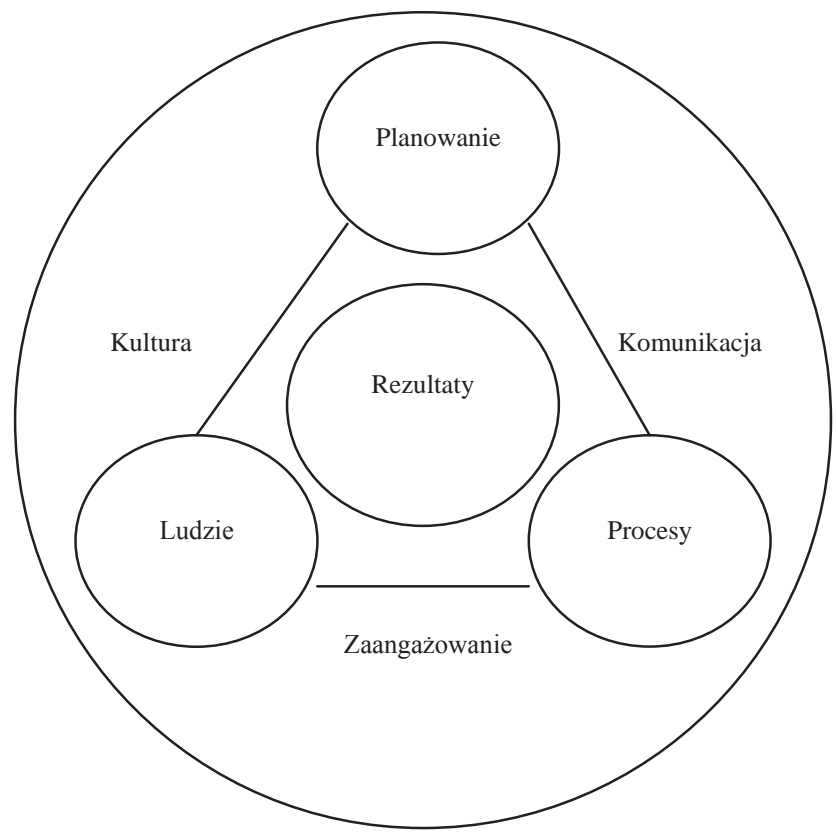

Ryc. 1. Nowa struktura zarządzania przez jakość TQM

Źródło: Oakland 2004, s. 36; Łańcucki 2006, s. 25

Bo Bergman i Bengt Klefsjö uważają natomiast, że liczba, a także treść i ranga elementów składających się na kompleksowe zarządzanie przez jakość ulegają ciągłej zmianie. Przyczyniają się do tego zmieniające się warunki wewnętrzne funkcjonowania poszczególnych organizacji (stosowane materiały, surowce, technika i technologia wytwarzania, organizacja pracy i produkcji, poziom kwalifikacji pracowników itp.), a także warunki zewnętrzne 
(konkurencja w branży w skali krajowej i międzynarodowej, regulacje prawne, koniunktura gospodarcza, polityka gospodarcza państwa itp.).

Zdaniem B. Bergmana i B. Klefsjö'a TQM stanowi system zarządzania składający się z wartości, metod, procedur i narzędzi. Celem systemu jest wzrost satysfakcji klientów wewnętrznych i zewnętrznych połączony ze zmniejszeniem zużycia zasobów (Łańcucki 2006, s. 25; Bergman, Klefsjö 2003, s. 400). Ten sposób definiowania systemu TQM okazuje się być szczególnie przydatny w praktyce. Wytłumaczeniem może tu być fakt, iż presja globalizacji, szybkie rozpowszechnianie się zmian technicznych i technologicznych sprawiają, że obecnie decydującą rolę we wprowadzaniu TQM w organizacjach zaczynają odgrywać wartości zaliczane do tzw. miękkich elementów TQM (np. kultura organizacji, zaufanie, praca zespołowa i zadowolenie $\mathrm{z}$ tej pracy, zaangażowanie wszystkich pracowników, delegowanie uprawnień, skupienie uwagi na klientach) (Łańcucki 2006, s. 26). Koncepcje zarządzania przez jakość odnoszą się głównie do praktyki przedsiębiorstw produkcyjnych, gdyż w działalności ich najczęściej pojawiały się problemy jakości. Koncepcje te opierają się na użytkowym pojmowaniu jakości i odpowiadają wprost na zapotrzebowanie praktyki.

Należy tu zauważyć, że nie ma jednej spójnej teorii TQM. Nie jest też możliwe dokonanie pełnej i wyczerpującej charakterystyki tej koncepcji. Natomiast poprzez kompilację wybranych propozycji zawartych w poszczególnych koncepcjach autorskich budowane są założenia TQM.

\section{Kultura ORGANiZACJI I JEJ ROLA W SYSTEMIE TQM}

Koncepcja Total Quality Management zakłada, że poprawa efektywności i konkurencyjności przedsiębiorstw powinna mieć swój początek w kreowaniu kultury organizacyjnej firmy, stanowiącej jeden z miękkich elementów systemu TQM, której podstawą jest odpowiednie ukształtowanie relacji pracowniczych. Punktem wyjścia w tym zakresie jest założenie, że każdy człowiek i każde jego działanie w sferze funkcjonowania przedsiębiorstwa ma określony wpływ na jakość, a „,zadowolenie klienta można osiagnąć tylko przy pomocy zadowolonych pracowników" (Steinberk 1998, s. 27).

Poprawę wydajności pracy, a tym samym efektywności całej firmy, implikującą wzrost konkurencyjności na rynku, można uzyskać poprzez ukształtowanie projakościowego klimatu w przedsiębiorstwie, którego inicjatorem powinno być naczelne kierownictwo organizacji. Proces tworzenia owego klimatu rozpoczyna formułowanie jednoznacznych, mierzalnych i osiagalnych celów firmy i takie ich przyporządkowanie poszczególnym pracownikom na każdym poziomie hierarchii organizacyjnej przedsiębiorstwa, by każda zatrudniona w firmie jednostka potrafiła zidentyfikować obszar, za który jest odpowiedzialna w możliwie szerokim zakresie. Działanie to pociaga za sobą zwiększanie swobody organizacyjnej poprzez kreowanie elastycznych zespołów zadaniowych z rozszerzonym zakresem uprawnień odpowiedzialności, przy jednoczesnym zawężeniu sztywnego podziału na stanowiska i zakresy czynności. Powoduje to wzrost oddolnej inicjatywy i zaangażowania pracowników w realizowane dzieło.

Kwestia delegowania uprawnień w dół hierarchii organizacyjnej jest istotnym elementem zarządzania rozwijającą się firmą. „Najlepsi menedżerowie wciąż na nowo dochodzą do wniosku, że przekazywanie władzy innym, zarówno współpracownikom jak i klientom, jest 
dla nich na dłuższą metę korzystne. Nagradzając, doceniając i dbając o doskonalenie kwalifikacji pracowników pozwalają, aby zasoby ludzkie organizacji, z którą mają do czynienia, zyskiwały na wartości. Im więcej dają władzy, tym lepsze wyniki pozwalają osiagnąć i tym większe sukcesy odnosi przedsiębiorstwo" (Chobać 2003).

Możliwość samodzielnego działania jednostki w obrębie przydzielonych jej obowiązków uwarunkowana jest funkcjonowaniem otaczającej ją sfery elementów funkcyjnych (pozostałych jednostek lub zespołów zadaniowych). TQM promuje sprzężenie poszczególnych odcinków realizacyjnych w obrębie określonego procesu wyodrębnionego w organizacji w celu optymalizacji przepływu informacji, a tym samym całego procesu. Koncepcje integracji jednostek funkcyjnych (w obrębie procesu) przedstawia ryc. 2.

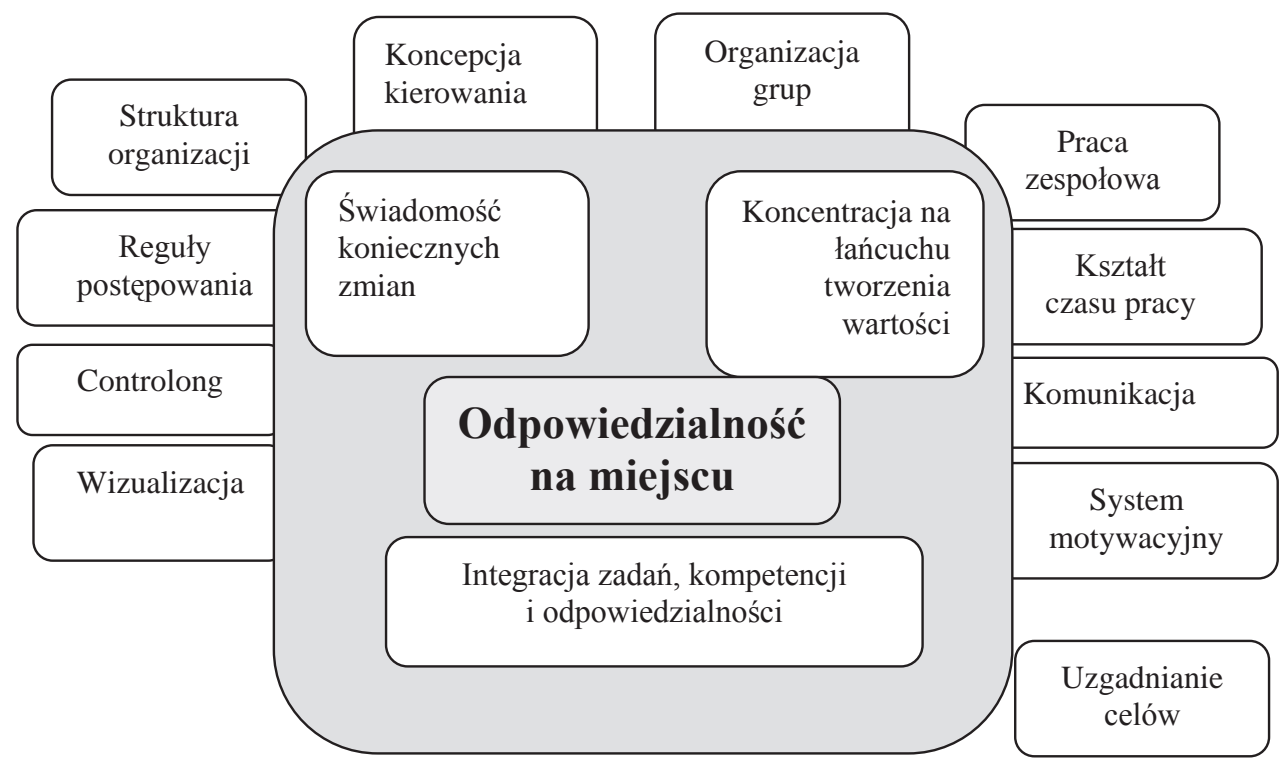

Ryc. 2. Przyporządkowanie odpowiedzialności w obrębie procesu

Źródło: Chobać 2003

Jakość, oznaczająca ogół właściwości wyrobu lub usługi decydujących o jego zdolności do zaspokajania stwierdzonych lub przewidywanych potrzeb, to dążność do zaspokojenia w pełni wszystkich oczekiwań klienta, w rozumieniu - odbiorcy oferty przedsiębiorstwa, czyli klienta zewnętrznego. W miejsce przywołanej rutyny koncepcja TQM wprowadza pełną koncentrację na kliencie tak zewnętrznym, jak i wewnętrznym i jego oczekiwaniach.

Uzgodnienie i zaspokojenie wymagań klienta wewnętrznego tworzy łańcuch wartości, który w myśl powyższych rozważań przekłada się w efekcie końcowym na jakość oferty i wymagania klienta zewnętrznego. Jest to punkt wyjścia do procesu tworzenia kompleksowej jakości. Taka technika zarządzania podkreśla istotę i rolę poszczególnych ogniw w łańcuchu procesów wyodrębnionych w przedsiębiorstwie. Wskazuje na każdy element składowy budujący cykl realizacyjny danego przedsięwzięcia i etapy wzbogacania produktu lub usługi o indywidualny wkład pracy współtworzącego ofertę członka organizacji. Zastosowanie takiego podejścia wymaga odpowiedniego podziału kompetencji funkcyjnych w przedsiębiorstwie, których zarys prezentuje diagram władzy Hackmana (ryc. 3). 


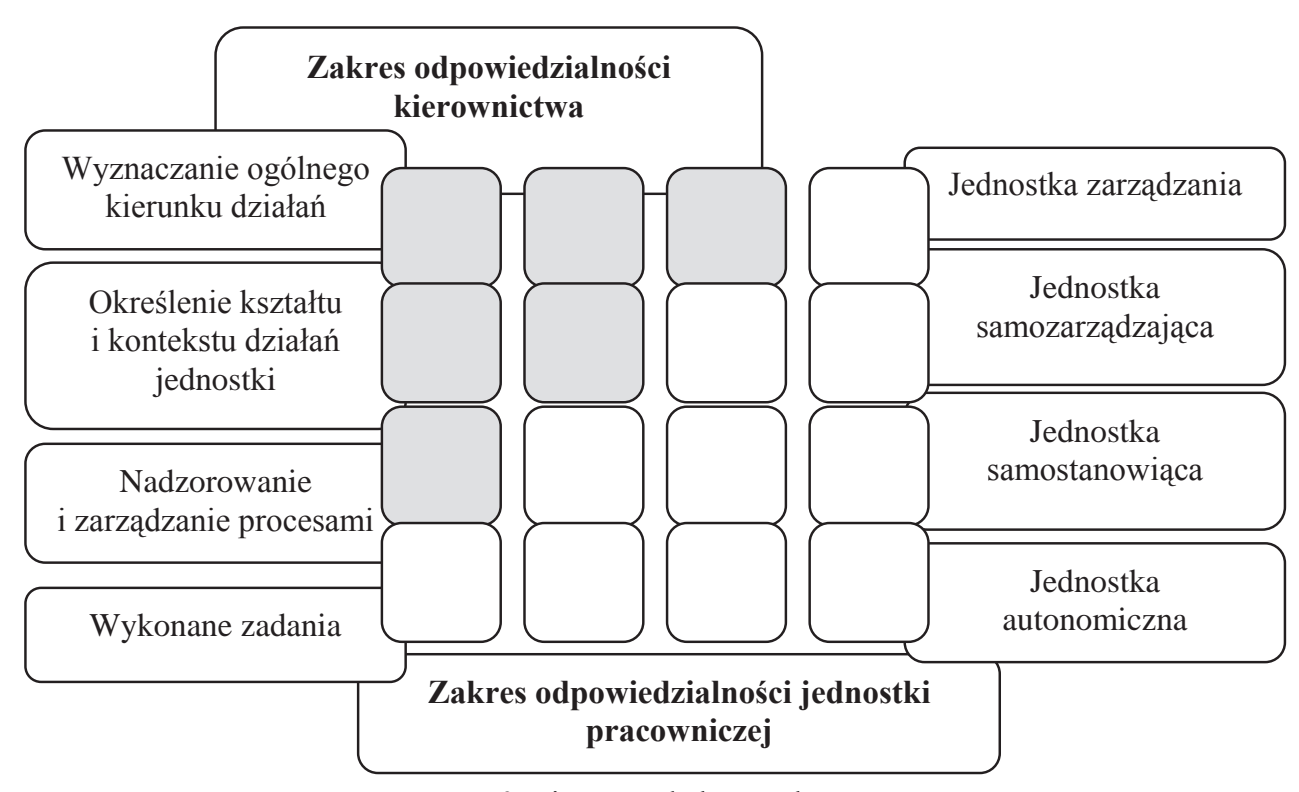

Ryc. 3. Diagram władzy Hackmana

Źródło: opracowanie własne na podstawie Bank 1997, s. 53

Podejście do nowej kultury organizacyjnej wyrastającej na kanwie przesłanek TQM, jako udziału wzajemnie przenikających się systemów (technicznego i społecznego), wymaga przeobrażenia istniejącej kultury organizacyjnej firmy w nową logikę jakości, otwartą na nieustanne doskonalenie (Kraszewski, Buszko 2002).

Wymodelowanie odpowiedniego gruntu do rozwoju przedmiotowej kultury, to między innymi dostrojenie elementu społecznego przedsiębiorstwa poprzez:

- selekcję pracowników pod kątem pożądanych umiejętności i doświadczeń do realizowanych zadań,

- delegowanie pracowników do nowych zadań,

- szkolenie pracowników z zakresu nowej filozofii organizacyjnej,

- prezentowanie nowych celów i misji przedsiębiorstwa, a także planów strategii i wyników firmy,

- kształtowanie projakościowych postaw i partnerskich stosunków zatrudnionej kadry,

- angażowanie ludzi w rozwój nowego stylu zarządzania i generowanie konstruktywnych pomysłów przyspieszających proces dokonywanych zmian (Karaszewski 2001, s. 93).

Osiagnnięcie wymaganego poziomu czynnika osobowego w organizacji jest warunkiem zapewniającym odpowiedni model przepływu informacji w obrębie firmy i stanowi fundament pod budowę sprawnej kultury organizacyjnej przedsiębiorstwa. W organizacjach zorientowanych na sukces komunikacja pomiędzy poszczególnymi szczeblami drabiny władzy i współpracownikami przebiegać powinna w sposób harmonijny oraz zapewniać pełny dostęp pracowników do aktualnych informacji. Czynnik osobowy i zasoby informacyjne przedsiębiorstwa stanowią najpoważniejszy kapitał przedsiębiorstwa uczącego się, zorientowanego na zarządzanie wiedzą. Zobowiązanie się całego przedsiębiorstwa do utrzymania jakości wymaga określenia założeń i sposobów postępowania odnośnie do polityki jakości. Wszyscy pracownicy przedsiębiorstwa powinni znać i rozumieć cele, jakie stoją przed nimi. 
Dobrze sformułowana polityka jakości jest środkiem zdobywania zaufania klienta i stanowi założenia strategii projakościowej przedsiębiorstwa.

Podstawowe zobowiązania wynikające z polityki jakości powinny być zrozumiałe dla wszystkich, stopniowo konkretyzowane, ukierunkowane na wszystkie płaszczyzny działań przedsiębiorstwa, a także uzupełniane poprzez dwukierunkowy przepływ informacji. Polityka jakości powinna być sformułowana i szczegółowo opisana na poszczególnych szczeblach hierarchii. Proces ten, nazywany rozwinięciem polityki jakości (Quality Policy Deployment), umożliwia postawienie realnych zadań w poszczególnych obszarach działania przedsiębiorstwa. Bez niego polityka pozostaje tylko na papierze i nie przynosi właściwych rezultatów.

\section{WYBRANE NARZĘDZIA ORAZ ICH ROLA W SYSTEMIE TQM}

Zasadniczym zadaniem narzędzi zarządzania przez jakość jest zbieranie i przetwarzanie danych związanych z różnymi aspektami jakości. Stanowią one instrumenty nadzorowania i diagnozowania procesów projektowania, wytwarzania, kontroli, jak również wszystkich innych działań współtworzących cykl istnienia wyrobu lub usługi. Ich znaczenie wynika z faktu, iż jedynie posiadanie rzetelnych i pełnych informacji pozwala na podejmowanie skutecznych działań w zakresie systematycznego doskonalenia jakości. Wyróżnia się stare narzędzia jakości, nazywane również tradycyjnymi, nowe narzędzia jakości, nazywane również współczesnymi oraz narzędzia wspomagające (za Bonstingl 1995, s. 85-112; Hamrol, Mantura 1998, s. 210-219).

Do tradycyjnych narzędzi zalicza się: schemat przebiegu procesu (,schemat blokowy”), wykres przyczynowo-skutkowy Ishikawy (technika „rybich ości”), wykres Pareto (diagram Pareto-Lorenza), wykres rozrzutu (wykresy zmiennych, wykres korelacji), arkusz kontrolny (lista zbiorcza, arkusz częstości zdarzeń), histogram (diagram słupkowy, wzorzec zmienności odchyleń), karty kontrolne (karty sterowania jakością, karty Shewharta). Dwa pierwsze narzędzia wykorzystują dane nieliczbowe, dlatego określa się je jako logiczne lub jakościowe, natomiast pięć pozostałych opiera się na danych ilościowych i określa się je jako statystyczne lub ilościowe.

Do współczesnych narzędzi i technik zalicza się: schemat pokrewieństwa (diagram powinowactwa), diagram zależności (diagram relacji), diagram drzewa (diagram systematyki), diagram tablicowy, tablicową analizę danych, wykres programowania procesu decyzji (PDPC), diagram sieciowy.

Siedem narzędzi wspomagających to: analiza pola sił, burza mózgów, benchmarking, empowerment, przeprojektowanie organizacyjne, modele organizacyjne oraz wskaźniki statystyczne (Szczepańska 2009, s. 72-197).

Schemat blokowy, nazywany również mapą procesu lub harmonogramem działań, to graficzna prezentacja wszystkich etapów przebiegu procesu od momentu jego rozpoczęcia do momentu jego zakończenia. Narzędzie to pozwala na zrozumienie i analizę przebiegu procesu oraz przyczynia się do poprawy jego jakości przez wprowadzenie korekty lub modyfikacji. Schematy blokowe najczęściej wykorzystywane są w procesach planowania i kontroli.

Wykres przyczynowo-skutkowy Ishikawy umożliwia systemowe ujmowanie i szeregowanie czynników wpływających na dane zjawisko, powodujących określony skutek, jak również pokazanie ich wzajemnej więzi. Wykres Ishikawy wykorzystuje się do identyfikacji 
czynników odpowiedzialnych za powstanie badanych problemów oraz do planowania procesu. W celu identyfikacji zaistniałego problemu za pomocą techniki „,rybich ości”, wpisuje się najpierw w „głowę” ryby problem, będący skutkiem. Następnie na większych „ościach” umieszcza się główne czynniki, które mogą stanowić powód zaistniałego skutku. Natomiast na małych „ościach” wpisuje się czynniki, które mogą się składać na czynniki główne, mogą się do nich przyczyniać lub je modyfikować. Wykres Ishikawy może być również wykorzystywany do planowania procesu doskonalenia.

Diagram Pareto-Lorenza opiera się na stwierdzonej empirycznie zasadzie, mającej swoje odniesienie do różnych zjawisk występujących w przyrodzie, systemach technicznych, społecznych, gospodarczych. Zasada ta mówi, że zazwyczaj 20\% przyczyn (czynników) decyduje o około 80\% ich skutków. Zasada ta nazwana została zasadą Pareto lub zasadą 80:20. Zgodnie z tą zasadą należy wnikliwie analizować dane, by rozpoznać kilka istotnych czynników, które wymagają największej uwagi. Zdiagnozowanie przyczyn zaistniałego problemu pozwala na wyznaczenie kierunków dalszych działań i na efektywne udoskonalenie procesów oraz podnoszenie jakości wyrobów lub usług. Wykres Pareto to wykres słupkowy, na którym czynniki wpływające na dany proces są uporządkowane od najważniejszych lub najczęściej występujących do najmniej istotnych lub najrzadszych.

Wykres korelacji służy do graficznego przedstawienia relacji między dwiema zmiennymi (cechami). Uzyskane rozmieszczenie punktów na osiach współrzędnych poddaje się analizie. Korelacja między danymi może mieć różny charakter: pozytywny, negatywny lub obojętny. Jeśli między dwoma badanymi czynnikami istnieje zależność, wskazująca na możliwość istnienia związku przyczynowo-skutkowego, punkty na wykresie będą się układać w kierunku od lewego dolnego do prawego górnego rogu. Jeśli natomiast punkty na wykresie są rozproszone lub ułożone wzdłuż prostej prostopadłej do jednej z osi układu współrzędnych, oznacza to, że badane wielkości nie są skorelowane.

Wykres korelacji wykorzystywany jest do rozpoznawania możliwych związków przyczynowo-skutkowych między czynnikami w danym procesie.

Histogram to rodzaj diagramu słupkowego, wykorzystywany w celu pokazania przebiegu zmian, wizualnego przedstawienia informacji o przebiegu procesu oraz podejmowania decyzji dotyczących wyboru miejsc, w których konieczne jest doskonalenie procesu. W sytuacji, gdy zjawisko lub proces zachodzi bez ingerencji z zewnątrz, histogram przedstawia rozkład normalny, przyjmujący większe wartości w pobliżu środka.

Arkusz kontrolny (lista zbiorcza) jest narzędziem służącym do zbierania, grupowania i zapisywania danych, które stanowią podstawę dalszych analiz. Ten uporządkowany sposób gromadzenia informacji umożliwia również identyfikację ich struktury.

Karty kontrolne (karty Shewharta) zalicza się do najistotniejszych technik statystycznej kontroli procesu. Wykorzystywane są do oceny stabilności procesu, ustalenia, kiedy proces wymaga regulacji, a kiedy należy go pozostawić takim, jaki jest. Poprzez karty kontrolne można również potwierdzić, że proces został udoskonalony. Na osi poziomej formularza zaznacza się czas, zaś na pionowej system lub proces, który poddawany jest procesowi kontroli. Gdy proces przekroczy górny lub dolny limit kontrolny, uznaje się, że jest on „poza kontrolą statystyczną". W takim przypadku niezbędne jest doregulowanie systemu, by proces znów znalazł się w granicach kontroli.

Współczesne narzędzia są uzupełnieniem narzędzi tradycyjnych. Stanowią one ważną pomoc w rozwiązywaniu problemów. Umożliwiają porządkowanie obiegu informacji i ich efektywną wymianę. 
Schemat pokrewieństwa służy przede wszystkim do zbierania, porządkowania i logicznego przedstawiania rozproszonych danych i pomysłów zebranych np. w efekcie „,burzy mózgów". Owo porządkowanie polega na tworzeniu nie więcej niż dziesięciu kategorii pojęć. Skonstruowany diagram pokrewieństwa jest punktem wyjścia do dalszej pracy z innymi narzędziami, takimi jak diagram Ishikawy lub diagram relacji.

Diagram zależności (diagram relacji) służy do uporządkowania informacji i przedstawienia, które czynniki wpływają na określony problem oraz jakie zależności występują między tymi czynnikami. Analizowane zależności przyczynowo-skutkowe przedstawiane są za pomocą strzałek łączących wiele różnych obiektów. Diagram ten różni się od diagramu Ishikawy tym, że nie uwzględnia hierarchicznego podziału przyczyn i dopuszcza zależności między wszystkimi obiektami na wykresie.

Wykres drzewa wykorzystywany jest w celu określenia problemów badawczych, wariantów decyzji oraz prawdopodobieństwa otrzymania każdego z wyników. Służy on do zbudowania systematyki obiektów poprzez hierarchiczne rozbicie danego zjawiska na mniejsze części.

Diagram tablicowy (wykres macierzowy) wykorzystywany jest w celu przedstawienia powiązań i zależności między wieloma zmiennymi. Związki te są zaznaczane symbolicznie (przy pomocy znaków oznaczających np. „,brak związku”, „słaby związek dodatni”, „silny związek ujemny"). Jest to narzędzie wykorzystywane do analizowania wpływu oraz skutków wywieranych przez określony czynnik na badany obszar konsekwencji.

Tablica analizy danych to ilościowe narzędzie umożliwiające identyfikację struktury dużych zbiorów danych. Podstawą analizy danych macierzowych jest zastosowanie metody głównych składowych. Pierwsza główna składowa objaśnia większość wariancji w oryginalnych obserwacjach. Technika ta jest wykorzystywana do tzw. pozycjonowania wyrobów, czyli takiego wyznaczania wartości ich cech, by mogły skutecznie w oczach klientów konkurować z wyrobami innych firm.

Wykres programowania procesu decyzji wykorzystuje się do analizy wszystkich możliwych problemów, jakie mogą zaistnieć, rozpoczynając od identyfikacji problemu, a kończąc na jego rozwiązaniu. Uzyskane wyniki umożliwiają sprecyzowanie alternatywnych środków zapobiegawczych, które będzie można zastosować w wypadku wystąpienia przewidzianych problemów. Można więc powiedzieć, że zastosowanie tego diagramu pozwala na planowanie działań w przypadku zaistnienia przewidywanych zdarzeń utrudniających osiągnięcie celu.

Wykres strzałkowy to graficzne przedstawienie struktury przedsięwzięcia lub projektu za pomocą sieci - grafu. Służy do planowania czasu wykonania procesu składającego się z wielu czynności.

Wszystkie wyżej wymienione metody są zazwyczaj określane jako jakościowe, czyli korzystające $z$ danych werbalnych i niejako porządkujące ukrytą wiedzę posiadaną przez osoby stosujące te metody. Jedyną ilościową metodą w zbiorze siedmiu nowych narzędzi jest analiza danych macierzowych

Natomiast narzędzia wspomagające, zaliczane również do metod zdobywania, porządkowania i analizowania danych, są pomocne w osiąganiu jakości, jednak nie są samym procesem, istotą zarządzania przez jakość. 


\section{Podstawowe WARUnKI SKUTECZnEJ IMPLEMENTACJ SYSTEMU TQM}

W celu wprowadzania oraz stałego doskonalenia systemu TQM w przedsiębiorstwie opracowano program Dziewięciu Filarów Zarządzania przez Jakość. Program ten pomyślany jest jako wsparcie wysiłków kierownictw i załóg na rzecz doskonalenia TQM poprzez wdrożenie w przedsiębiorstwie dziewięciu mocnych filarów doskonalenia zarządzania przez jakość.

Filary TQM mają uniwersalny charakter. Umożliwiają one wdrażanie, ocenianie oraz doskonalenie TQM w przedsiębiorstwie. Każdy filar posiada swoje kryterium, które jest jego nazwą i określa jego właściwość - charakter. Nazwy kryteriów zaczerpnięto z Polskiej Nagrody Jakości, która jest oparta na koncepcji Europejskiej Nagrody Jakości. W tabeli 1 przedstawiono charakterystykę poszczególnych filarów TQM. Filary I-V charakteryzują potencjał przedsiębiorstwa, natomiast filary VI-IX efekty jego działalności.

Tab. 1. Interpretacja obszarów oceny

\begin{tabular}{|l|l|l|}
\hline \multicolumn{1}{|c|}{ Filar } & Kryterium (obszar oceny) & \multicolumn{1}{|c|}{ Opis } \\
\hline Filar I & Przywództwo & $\begin{array}{l}\text { Ocenia osobiste zaangażowanie przywódców (dyrektora/ } \\
\text { prezesa oraz innych kierowników) w realizację misji i wizji, } \\
\text { rozwijanie wartości potrzebnych do osiagania długofalowe- } \\
\text { go sukcesu oraz wdrażania i ciągłego doskonalenia systemu } \\
\text { zarządzania organizacja, jako zasadniczego procesu uzyski- } \\
\text { wania ciagłej poprawy. }\end{array}$ \\
\hline Filar II & Strategia i polityka & $\begin{array}{l}\text { Odnosi się do podstawowych wartości, którymi kieruje się } \\
\text { organizacja. Dotyczy wdrażania misji i wizji poprzez czy- } \\
\text { telne sformułowanie strategii organizacji. Strategia powinna } \\
\text { być ukierunkowana na wszystkich zainteresowanych funk- } \\
\text { cjonowaniem organizacji oraz wskazywać, w jaki sposób } \\
\text { przekłada się ona na odpowiednią politykę, plany, założe- } \\
\text { nia, cele i procesy. }\end{array}$ \\
\hline Filar III & Zarządzanie ludźmi & $\begin{array}{l}\text { Określa, w jaki sposób wykorzystanie potencjału ludzkiego } \\
\text { jest ukierunkowane na działania wspierające cele strategicz- } \\
\text { ne, politykę, efektywność działania procesów, a w rezultacie } \\
\text { na poprawę efektów końcowych organizacji. Pokazuje, jak } \\
\text { zarządza się ludźmi, rozwija wiedzę oraz wyzwala pełny po- } \\
\text { tencjał pracowników na poziomie indywidualnym, zespoło- } \\
\text { wym i całej organizacji, aby sprostać powyższym zadaniom. }\end{array}$ \\
\hline Filar IV & Zarządzanie zasobami & $\begin{array}{l}\text { Odnosi się do zarządzania, wykorzystania i ochrony zaso- } \\
\text { bów, sposobów ich optymalizacji oraz sposobów zarządza- } \\
\text { nia swoimi relacjami z zewnętrznymi partnerami w celu } \\
\text { realizacji strategii i polityki oraz zapewnienia efektywności } \\
\text { procesów. }\end{array}$ \\
\hline $\begin{array}{l}\text { Odnosi się do sposobu określania, zarządzania i doskonale- } \\
\text { nia procesów, co powinno wpływać na wzrost ich wartości, } \\
\text { przyczyniając się w ten sposób do wspierania strategii } \\
\text { i polityki, pełnego zaspokojenia potrzeb klientów oraz in- } \\
\text { nych zainteresowanych funkcjonowaniem organizacji. }\end{array}$ \\
\hline
\end{tabular}




\begin{tabular}{|l|l|l|}
\hline Filar VI & Satysfakcja klientów & $\begin{array}{l}\text { Określa, co organizacja osiaga w relacjach ze swoimi } \\
\text { klientami zewnętrznymi, a szczególnie jak zaspokaja ich } \\
\text { potrzeby. }\end{array}$ \\
\hline Filar VII & Satysfakcja zatrudnionych & $\begin{array}{l}\text { Odzwierciedla stosunek załogi do naczelnego kierownictwa, } \\
\text { bezpieczeństwa socjalnego, awansów oraz do tego, co orga- } \\
\text { nizacja osiaga w relacjach z własnymi pracownikami. }\end{array}$ \\
\hline Filar VIII & Współpraca z otoczeniem & $\begin{array}{l}\text { Odnosi się do percepcji organizacji w oczach opinii publicz- } \\
\text { nej, jak również do tego, co organizacja osiaga w relacjach } \\
\text { ze społecznością (lokalną, krajową, międzynarodową). }\end{array}$ \\
\hline Filar IX & Efekt końcowy & $\begin{array}{l}\text { Odnosi się do osiagnięć przedsiębiorstwa w stosunku do } \\
\text { zaplanowanych celów w zakresie całokształtu jego rozwoju } \\
\text { oraz zaspokojenia potrzeb wszystkich stron zainteresowa- } \\
\text { nych jej działalnością. }\end{array}$ \\
\hline
\end{tabular}

Źródło: Polska Nagroda Jakości 2002, s. 7

Implementacja i doskonalenie jakości i zarządzania przez jakość powinny rozpoczynać się od zmiany mentalności kierownictwa i załogi. Pracownicy powinni pracować w określonym systemie jakości, kierownictwo powinno pracować nad systemem, doskonaląc go przy pomocy pracowników. Dlatego:

- włączenie naczelnego kierownictwa do programu poprawy jakości jest podstawą sukcesu; wyrażenie przez kierownictwo akceptacji nie jest aktem wystarczającym;

- wszystkie systemy organizacyjne mogą być dostatecznie zrozumiane tylko przez stosowanie języka i metod statystycznych;

- inspekcja procesów jest podobnie ważna jak inspekcja wyrobów gotowych i może być dobrze prowadzona przez samych pracowników uczestniczących w procesie;

- system zarządzania przez jakość powinien obejmować całe przedsiębiorstwo, wszystkie komórki organizacyjne, jego dostawców i klientów, wszystkie fazy tworzenia wyrobu: marketing, logistykę, finanse, planowanie, badania, rozwój, projektowanie, dostawców, produkcję, sprzedaż, serwis oraz otoczenie zewnętrzne przedsiębiorstwa;

- użytkowy produkt znajduje się w cyklu tworzenia wyrobu i musi być nadal obiektem zainteresowania producenta;

- każdy kierownik powinien określić cele podległych jednostek organizacyjnych oraz wskazać metody ich osiągnięcia;

- należy pozbyć się sloganów;

- $85 \%$ przyczyn błędów jest skutkiem wad systemu, a tylko $15 \%$ przyczyn obciąża pracowników.

Aby wdrożyć koncepcję TQM, należy zmienić wiele starych przyzwyczajeń, a przed wszystkim kulturę pracy załogi i kierownictwa. W pierwszym rzędzie należy przetransformować mentalność pracy załogi i kierownictwa z pasywnej na aktywną. Wiąże się to z upełnomocnieniem pracowników, spowodowaniem, by każdy pracownik był odpowiedzialny za jakość, wprowadzeniem prewencji poprzez zapobieganie złej jakości, wprowadzeniem i realizowaniem samokontroli. W rezultacie takiego podejścia przedsiębiorstwo osiagnie wysoki zysk, dobrą opinię u klientów, zmniejszy koszty produkcji, stanie się producentem wyrobu lub usługi klasy europejskiej lub światowej.

Czyniąc odpowiedzialnym za jakość tylko określoną grupę ludzi w przedsiębiorstwie, pozostałym pracownikom przekazywany jest sygnał, że nie muszą się tym martwić. Dlatego 
należy podkreślać, że każdy pracownik w przedsiębiorstwie odpowiada za jakość wykonanej pracy. Ukształtowanie właściwego podejścia pracownika do jego pracy w przedsiębiorstwie, czyli transformacja mentalności, wymaga:

- wyjaśnienia długoterminowej strategii i celów,

- zrozumienia zadań, których realizacja jest oczekiwana,

- demonstrowania, jak zadania wspierają całokształt działalności,

- znajomości czynności i potrzeb kooperujących jednostek,

- osobistego współtworzenia przykładu przez ,szefa” i kierownictwo,

- fachowego szkolenia i treningów,

- osobistego uznania i udziału w sukcesie,

- wsłuchiwania się kierownictwa w głos załogi i uwzględniania propozycji pracowników,

- szkolenia wytrwałości i cierpliwości.

Jakość w wielu przedsiębiorstwach jest odnoszona do norm wykonania produktu lub usługi. Natomiast tak naprawdę jakość końcowego efektu pracy przedsiębiorstwa, jaką jest wyrób lub usługa, jest tylko jednym $\mathrm{z}$ aspektów jakości pracy i zarządzania. W przedsiębiorstwie, które myśli kategoriami TQM, jakość obejmuje wszystko, od dostawców aż do ostatecznego klienta otrzymującego gotowy produkt lub usługę. Obejmuje więc całą sferę organizacji zarządzania przedsiębiorstwem.

Pracownicy w przedsiębiorstwie znajdują się w środku łańcucha dostawca-klient. Otrzymują oni półprodukty od wewnętrznego dostawcy i przetwarzają je dla klienta wewnętrznego w tym łańcuchu. W przedsiębiorstwie stosującym zasady TQM jakość nie jest tylko czymś, co jest przeznaczone dla ostatecznego odbiorcy. Przeciwnie, w takim przedsiębiorstwie każda działalność w łańcuchu dostawca-klient ma wymiar jakościowy. Działalność każdego pracownika przedsiębiorstwa musi mieć sens i być dobrze wykonana. Poza jakością produktu ważna jest również jakość związków z dostawcą, klientem, terminowością dostaw, ponoszonymi kosztami przez klienta itp. Dotyczy to również związków z lokalną społecznością oraz ochroną środowiska.

Do ciąłłego sterowania procesem TQM w przedsiębiorstwie potrzebny jest zespół kierujący. Ponieważ TQM jest pierwszoplanowym zadaniem, osoba z kierownictwa przedsiębiorstwa powinna przejąć dodatkowo zadania kierowania zespołem TQM. Implementacja TQM w przedsiębiorstwie tylko wtedy może przynieść korzyści, jeżeli pracownicy będą odpowiednio przeszkoleni. Konieczne jest zarówno intensywne szkolenie kierownictwa, jak i wszystkich pracowników. Szkolenie kierownictwa powinno obejmować przede wszystkim podstawy i elementy TQM, politykę jakości przedsiębiorstwa, zastosowanie metod do własnych zakładowych projektów, opracowanie specyficznych dla przedsiębiorstwa metod dalszego postępowania.

Należy podkreślić, że szkolenie należy prowadzić „od góry do dołu”, oczywiście w odpowiednim dla szkolonych zakresie. Równolegle ze szkoleniem należy brać pod uwagę następujące warunki:

- dostosowanie organizacji przedsiębiorstwa do wymagań kompleksowego zarządzania przez jakość produkcji i ponoszenie odpowiedzialności przez poszczególne stanowiska za realizację elementów systemu jakości,

- określenie, dysponowanie i przeznaczenie środków na wprowadzenie systemu zarządzania przez jakość,

- wybranie i określenie odpowiednich metod i narzędzi dla kompleksowego zarządzania przez jakość, 
- ciągłą analizę jakości z punktu widzenia systemu zarządzania przez jakość i jego usprawniania,

- powszechne stosowanie metod statystycznych w procesie produkcji,

- wprowadzenie systemu motywacji pracowników.

Kolejnym celem TQM jest wytworzenie i podtrzymywanie u pracowników wewnętrznej potrzeby stałej poprawy własnej pracy. Stosowane w tym celu środki to dobra informacja, stworzenie odpowiedniego klimatu, popieranie inicjatywy pracowników, odpowiedzialność za wyniki własnej pracy, określenie i ocena własnej pracy, udział w grupach poprawy jakości i grupach projektowych. Proces TQM wymaga również kontroli za pomocą audytów. Regularne audyty zapewniają stabilizację działań. Bardzo ważną sprawą jest też motywacja pracowników. Nic nie motywuje mocniej niż uznanie. Doświadczenia wykazują, że uznanie wyrażone przez przełożonego znacznie bardziej zwiększa motywację niż same tylko bodźce finansowe.

Działania w zakładzie mogą przyjmować różne formy. Często np. tworzone są przez kierownictwo specjalne zespoły zadaniowe. Są to interdyscyplinarne grupy ludzi, do których kierowane są specjalne zadania. W przypadku zadań szczególnie trudnych zespoły te mogą wymagać odpowiedniego przeszkolenia. Po wykonaniu zadania zespół może być rozwiązany lub powołany do innego zadania. Zespoły zadaniowe mogą być włączone zarówno do prac badawczych, jak i wdrożeniowych w zakresie systemów i technologii. Zasadniczym celem działania zespołów zadaniowych jest wykonywanie zadań priorytetowych wyznaczonych przez kierownictwo. Tak więc zespoły zadaniowe powstają w wyniku inicjatywy ogólnej.

Inny charakter i rolę mają grupy pracownicze, jak np. kręgi jakości. Ich zadaniem jest przede wszystkim wprowadzanie zmian kulturowych na szczeblu produkcyjnym. Są one tworzone przez ludzi pracujących w danym obszarze, zachęcanych do identyfikowania problemów, znajdowania i wdrażania rozwiązań. Kręgi jakości są elementem działań wynikających z inicjatywy oddolnej jako naturalna przeciwwaga do programu odgórnego realizowanego przez zespoły zadaniowe. Kręgi jakości to małe grupy pracowników, które angażują się z własnej inicjatywy we wspólne rozwiązanie problemów związanych ze swoja pracą. Grupy te bywają nazywane różnie, np. koło jakości, grupa postępu, grupa naprawcza, grupa rozwiązywania problemów, grupa poprawy jakości, grupa eureka, zespół postępu i innowacji. Każdy krąg działa w pewnym sensie jak mechanizm nadzoru, wspomagając przedsiębiorstwo w pokonywaniu przeszkód. Liczba członków kręgu zmienia się w zależności od polityki przedsiębiorstwa. Średnio krąg liczy 8-10 członków, którzy spotykają się regularnie, wymieniają doświadczenia, wykorzystując różne metody do rozwiązywania rzeczywistych problemów. Spotkania odbywają się w godzinach pracy za zgodą przełożonego lub poza godzinami z inicjatywy pracowników. Spotkanie prowadzi animator, którym najczęściej jest bezpośredni przełożony. Jednakże w tym przypadku nie posiada on przywileju szefa i nie może narzucać swego zdania grupie. Każdy krąg jest formalnie niezależny, ale może się łączyć z innym w celu wspólnej pracy. Uczestnictwo w kręgu jest dobrowolne i członkowie nie otrzymują z tego tytułu żadnych wynagrodzeń. 


\section{MAPA PROCESÓW OBJĘTYCH SYSTEMEM ZARZĄDZANIA JAKOŚCIĄ}

Pomocne w implementacji systemu TQM, w szczególności w przedsiębiorstwach przemysłowych, może okazać się opracowanie struktury systemu zarządzania przez jakość. Podstawę do opracowania owej struktury stanowi norma PN-EN ISO 9001 i opisane w niej podejście procesowe. Ryc. 4 przedstawia mapę procesów objętych systemem zarządzania, opracowaną dla przedsiębiorstwa przemysłowego działającego w branży rozlewniczej. Mapa przedstawia zidentyfikowane procesy wraz z wszystkimi powiązaniami. Szczegółowe powiązania pomiędzy czynnościami występującymi w procesach umieszczane są natomiast na schematach poszczególnych procesów.

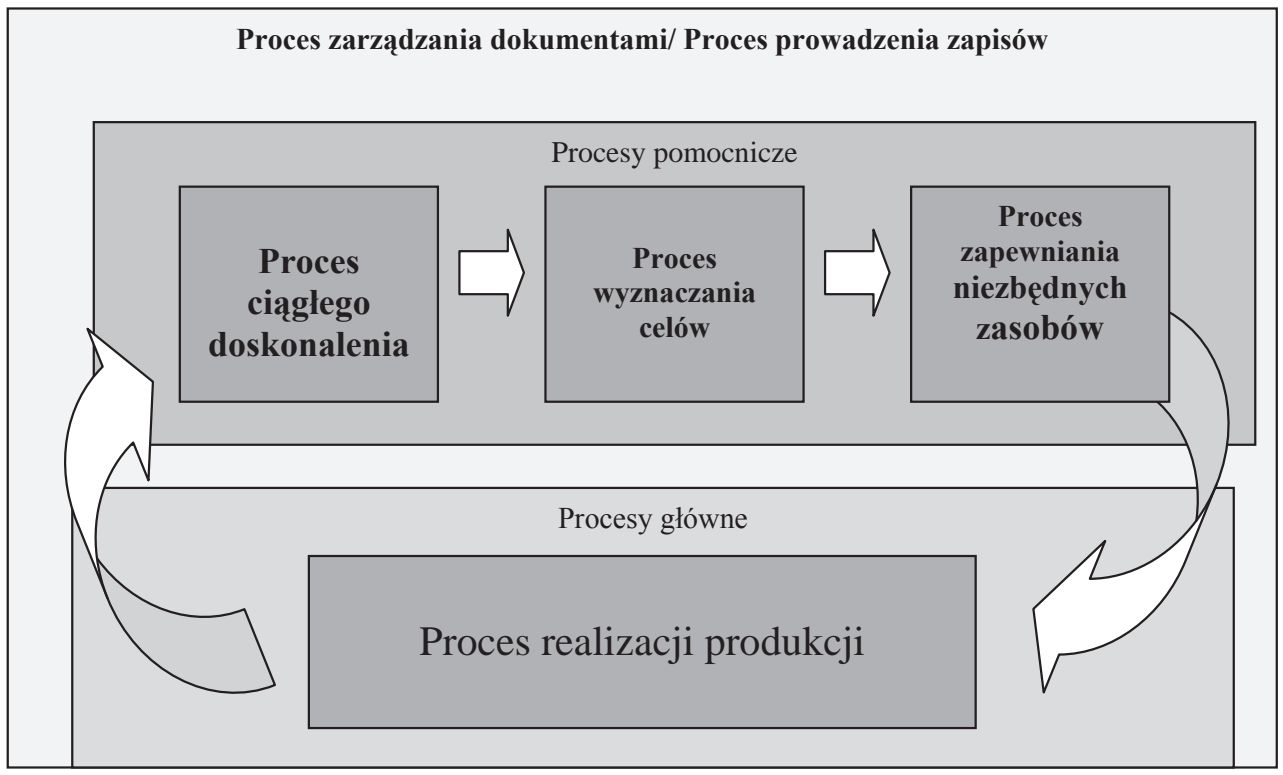

Ryc. 4. Mapa procesów objętych systemem zarządzania przez jakość

Źródło: opracowanie własne na podstawie Księgi Jakości przedsiębiorstwa produkcyjnego

Procesy powiązane bezpośrednio z działalnością przykładowego przedsiębiorstwa produkcyjnego to proces wyznaczania celów jakościowych, proces zapewniania niezbędnych zasobów, proces realizacji produkcji oraz proces ciagłego doskonalenia. Proces realizacji produkcji stanowi cel główny przedsiębiorstwa produkcyjnego. Pozostałe procesy są procesami pomocniczymi. Szczegółowy schemat procesu przedstawia wykonywane czynności wraz z powiązaniami, zarówno wzajemnymi, jak też z innymi procesami. Pozwala to na pełniejsze zobrazowanie przebiegu każdego z procesów. Ryc. 5 prezentuje przykładowy schemat procesu wyznaczania celów jakościowych.

Zaletą przyjętego podejścia jest włączenie w każdy proces sprzężenia zwrotnego zapewniającego doskonalenie. Określenie klientów procesu oraz dostarczanych im wyrobów pozwala na identyfikację oczekiwań klientów, a następnie taką organizację procesu, aby te oczekiwania były stale spełniane. Wiedza dotycząca klientów, wyrobów i warunków realiza- 
cji procesów umożliwia określenie wymagań dla materiałów wchodzących do procesu oraz ustalenie odpowiednich zasad współpracy z ich dostawcami. Wynikiem sprzężenia zwrotnego jest minimalizacja ryzyka związanego z zakłóceniami generowanymi przez proces oraz jego otoczenie, co prowadzi do podnoszenia skuteczności i efektywności.

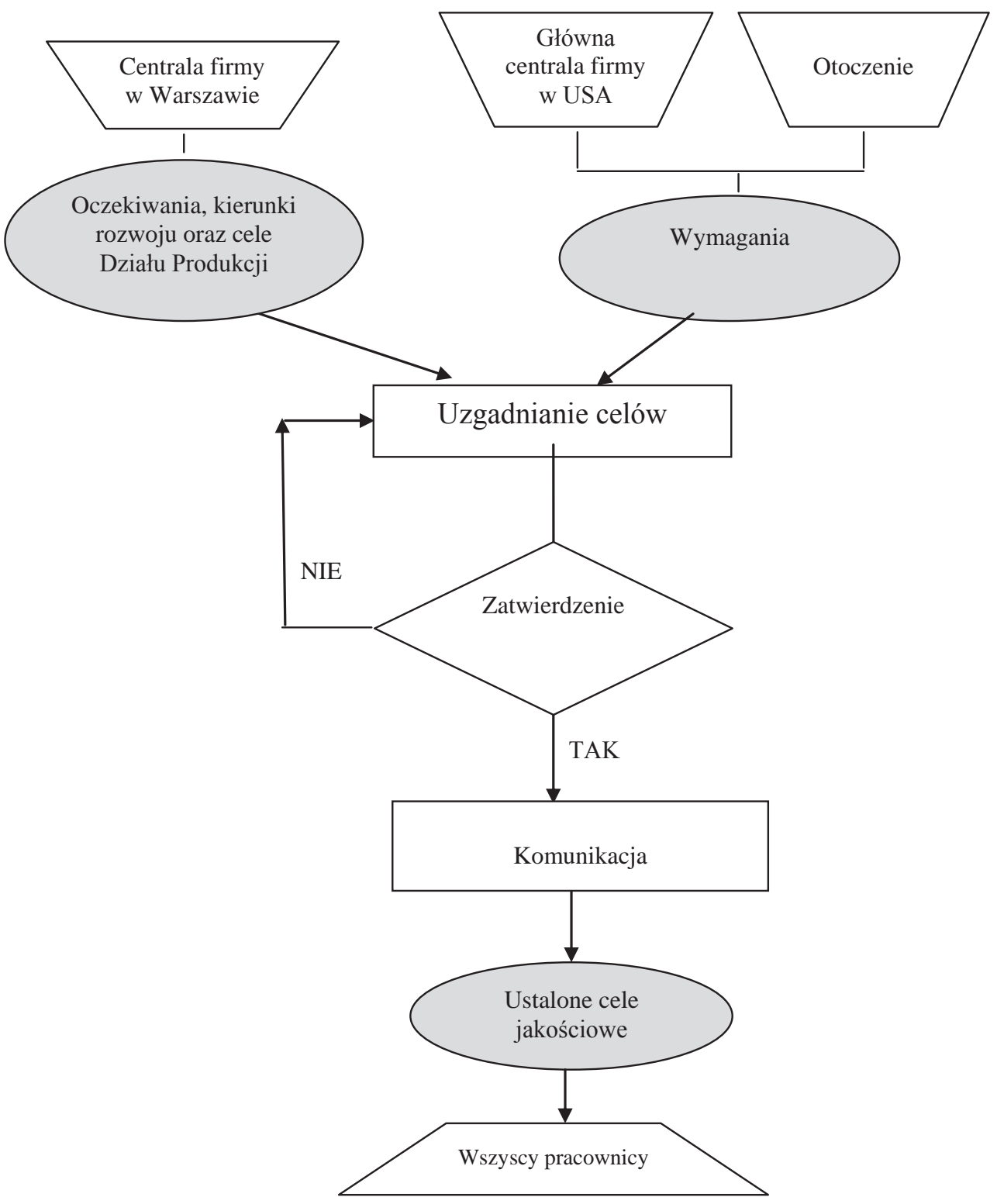

Ryc. 5. Schemat procesu wyznaczania celów jakościowych 


\section{ZAKOŃCZENIE}

Głównym celem przedsiębiorstwa jest osiagnięcie długotrwałego sukcesu finansowego, którego źródłem są zadowolenie klienta oraz korzyści dla organizacji i jej członków. Klient jest zadowolony wtedy, gdy otrzymuje wyrób dobrej jakości. Dlatego głównym celem przedsiębiorstwa jest ciagłe doskonalenie jakości wyrobów dla uzyskania pełnej satysfakcji klienta. Szczególnego znaczenia nabiera tu realizacja zasad TQM, czyli kompleksowego zarządza przez jakość.

Zasadniczym elementem mającym decydujący wpływ na poprawę funkcjonowania organizacji oraz ograniczenia kosztów jest zmiana sposobu myślenia pracowników oraz nastawienie na wysoką jakość wytwarzanych towarów oraz świadczonych usług. Jedynie wykwalifikowani, świadomi realizowanej misji oraz wewnętrznych i zewnętrznych współzależności pracownicy mogą pracować efektywnie, przynosząc tym samym zyski zatrudniającej ich organizacji. Wdrożenie systemu TQM jest jedyną właściwą drogą dającą duże korzyści wprowadzającemu ją zakładowi, satysfakcję pracownikom oraz pełne zadowolenie klientów.

\section{Literatura}

Bank J., 1997, Zarzqdzanie przez jakość, Gebethner i S-ka, Warszawa.

Bergman B., Klefsjö B., 2003, Quality, from Customer Needs to Customer satisfaction, Lund.

Bonstingl J.J., 1995, Szkoły jakości, Wprowadzenie do Total Quality Management w edukacji, CODN, Warszawa.

Chować E., 2003, Kapitat pracowniczy w kulturze organizacyjnej przedsiębiorstwa wykreowanej na bazie TQM, Problemy Jakości, nr 4.

Hamrol A., Mantura W., 1998, Zarzqdzanie jakościq. Teoria i praktyka, Wydawnictwo Naukowe PWN, Warszawa-Poznań.

Hill T., 1991, Production and operations management, Cambridge.

Karaszewski R., 1999, Total Quality Management. Zarzqdzanie przez jakość. Wybrane zagadnienia, Tonik, Torun.

Karaszewski R., 2001, TQM teoria i praktyka, Dom Organizatora, Toruń.

Karaszewski R., Buszko M., 2002, TQM a kultura organizacyjna, Problemy Jakości, nr 1.

Oakland J.S., 2004, Oakland on Quality Management, Elsevier Butterworth-Heinemann.

Podstawy Kompleksowego Zarzq̨zania Jakościq TQM, 2006, red. J. Łańcucki, AE w Poznaniu, Poznań.

Polska Nagroda Jakości, 2002.

Skrzypek E., 2000, Jakość i efektywność, Wydawnictwo UMCS, Lublin.

Steinbeck H.H., 1998, TQM Kompleksowe Zarzqdzanie Jakościa, Placet, Warszawa.

Szczepańska K., 2009, Metody i techniki TQM, Oficyna Wydawnicza Politechniki Warszawskiej, Warszawa. 


\section{Implementation of TQM system in improving the competitive position of industrial enterprises}

The main aim of each industrial enterprise is to achieve the long-term financial success. The source of that is customer satisfaction, benefits for organisation and its members. Customer is satisfied when he receives high quality product. Therefore the essential task of industrial enterprise is the continuous improvement of product quality. Realisation of TQM principles is of great importance.

The TQM philosophy is an innovative way of company management. It promotes building of comprehensive, individual organisational culture of enterprise with common aims and values. The change of philosophy of thinking and workers concentration on high quality products manufacturing are the principal factors which influence the increase of company's operations. Only these workers who are qualified and conscious about company's mission as well as internal and external dependencies, can work effectively.

Dr Anna Irena Szymańska

Uniwersytet Pedagogiczny, Kraków

Instytut Geografii

Zakład Przedsiębiorczości i Gospodarki Przestrzennej

e-mail: A.Szymanska@up.krakow.pl 